\title{
PERGURUAN ISLAM REPUBLIK INDONESIA YOGYAKARTA DAN TRANSMISI PENGETAHUAN GERAKAN AHMADIYAH INDONESIA
}

\author{
Husen Hasan Basri \\ Puslitbang Pendidikan Agama dan Keagamaan | Balitbang dan Diklat Kemenag RI \\ Jl. MH Thamrin No.6 Jakarta Pusat | Email: hhasanbasri@yahoo.com
}

\begin{abstract}
There are pros and cons to the existence of the Islamic University of Indonesia (PIRI). Some perceive it as a seeding site of Indonesian Ahmadiyah Movement (GAI) ideas and values. PIRI is alleged to have carried out knowledge transmission for GAI. But for some other, PIRI is a foundation organizing merely educational activities without any affiliation to GAI, especially with regard to such knowledge transmission. Through a qualitative research approach, it is found that PIRI was born from an idea of GAI founders that the spirit of GAI underlies the PIRI education activities. Most of the principals at PIRI schools indeed come from GAI. However, most of the teachers come from a variety of socio-religious backgrounds, and the students are from the community that has never been the followers of GAI. PIRI adopts curriculum produced by the Ministry of Education and Culture for secular subjects and that produced by the Ministry of Religious Affairs for Islamic as well as their PIRI (Ahmadiya)-specific subject matters. In conclusion, there is historical and spiritual relationship between PIRI and GAI and not organizational relationship. Although there are attempts of GAI knowledge transmission in PIRI, but education in PIRI schools is more oriented to their educational goals of integrating to social changes in the community, and conformity to the Indonesian national education system.
\end{abstract}

Keywords: PIRI, Knowledge Transmission, GAI.

\begin{abstract}
Abstrak
Ada pro dan kontra terhadap eksistensi Perguruan Islam Republik Indonesia (PIRI). Sebagian masyarakat melihat PIRI sebagai tempat penyemaian pemikiran dan nilai Gerakan Ahmadiyah Indonesia (GAI). PIRI diduga telah melakukan transmisi pengetahuan GAI. Tetapi bagi masyarakat lainnya, PIRI adalah sebuah yayasan yang murni menyelenggarakan kegiatan pendidikan dan tidak memiliki kaitan dengan GAI, apalagi berkaitan dengan transmisi pengetahuan GAI. Melalui pendekatan penelitian kualitatif ditemukan bahwa kelahiran PIRI berasal dari gagasan para pendiri GAI, sehingga ruh GAI melandasi beberapa kegiatan pendidikan di PIRI. Sebagian besar kepala sekolah pada sekolah-sekolah PIRI berasal dari GAI. Tetapi, guru-gurunya sebagian besar berasal dari berbagai macam latar belakang sosial keagamaan, dan asal siswanya dari masyarakat bukan pengikut GAI. Kurikulum yang digunakan adalah kurikulum Kementerian Pendidikan dan Kebudayaan untuk mata pelajaran umum. Sedangkan untuk pelajaran agama menggunakan kurikulum Kementerian Agama dan kurikulum kePIRI-an (ke-Ahmadiyahan-an). Kesimpulannya, ada hubungan historis dan keruhanian antara PIRI dan GAI, tetapi tidak ada hubungan organisatoris. Meskipun ada upaya transmisi pengetahuan GAI di PIRI, namun pendidikan di PIRI dengan lembaga sekolah-sekolahnya lebih mengorientasikan tujuan pendidikannya kepada pengintegrasian terhadap perubahan sosial di masyarakat, dan berkesuaian dengan sistem pendidikan nasional yang diterapkan di Indonesia.
\end{abstract}

Kata Kunci: PIRI, Transmisi Pengetahuan, GAI.

Naskah diterima 19 Juni 2014. Revisi pertama, 9 Juli 2014. Revisi kedua, 19 Juli 2014 dan revisi terahir 2 Agustus 2014. 


\section{PENDAHULUAN}

Perguruan Islam Republik Indonesia (PIRI) adalah sebuah perguruan Islam yang berdiri tahun 1947 di Yogyakarta. Pendirian PIRI dilatarbelakangi oleh alasan selain keinginan untuk menegakkan ajaran Islam juga untuk ikut berpartisipasi dalam melayani pendidikan masyarakat. ${ }^{1}$ Yayasan PIRI berkantor pusat di kota Yogyakarta. PIRI memiliki maksud dan tujuan di bidang sosial dan keagamaan. Di bidang sosial, PIRI mendirikan dan menyelenggarakan lembaga pendidikan formal dan non formal; melakukan pembinaan olahraga, dan melalukan penelitian di bidang ilmu pengetahuan dan studi banding. Dalam bidang keagamaan, PIRI mendirikan sarana ibadah, menyelenggarakan pondok pesantren dan madrasah, menerima dan menyalurkan amal, zakat, infaq, dan sedekah, meningkatkan pemahaman keagamaan Islam, melakukan syiar keagamaan, dan melakukan studi banding keagamaan.

Sampai saat ini, jalur dan jenis pendidikan yang diselenggarakan PIRI adalah pendidikan formal dalam bentuk sekolah yang meliputi TK, SD, SMP, SMA, dan akademi. ${ }^{2}$ PIRI memiliki sebuah kompleks pendidikan yang bertempat di Jalan Kemuning No. 14. Baciro Yogyakarta. Di kompleks ini, terdapat Sekolah Menengah Kejuruan dan Sekolah Menengah Atas. Selain di Baciro, PIRI juga memiliki sekolah di Nitikan Baru, Ngaglik Sleman. Sekolah-sekolah itu dinamakan baik oleh internal PIRI maupun masyarakat umum dengan sebutan "sekolah PIRI". PIRI telah memiliki puluhan ribu alumni

${ }^{1}$ PIRI adalah sebuah yayasan sebagaimana akte Yayasan PIRI tertanggal 16 April 1984, akte yayasan tertanggal 1 Agustus 1990, akte yayasan tertanggal 6 Januari 1998, akte penyesuaian anggaran dasar yayasan PIRI tertanggal 31 Juli 2007.

${ }^{2}$ Sampai September 2013, PIRI memiliki lembaga pendidikan TK di Nitikan Umbulharjo Yogyakarta, SD Nitikan Umbulharjo Yogyakarta, 2 (dua) SMP di Yogyakarta dan 1 (satu) SMP di Lampung, 4 (empat) SMK di Yogyakarta dan 1 (satu) SMK di Purwokerto, 2 (dua) SMA di Yogyakarta dan 1 (satu) SMA di Lampung, dan Akademi Teknik PIRI yang disingkat ATEKPI di Gedong Kuning Yogyakarta. yang tersebar di seluruh Indonesia. Realitas ini yang membuat masyarakat Yogyakarta melihat PIRI sebagai lembaga pendidikan.

Eksistensi PIRI dalam beberapa waktu yang lalu pernah dituduh mengajarkan paham dan ajaran Ahmadiyah. ${ }^{3}$ Secara historis, PIRI tidak bisa dipisahkan dari Gerakan Ahmadiyah Indonesia (GAI). GAI merupakan salah satu dari dua kelompok Ahmadiyah yang eksis dan berkembang di Indonesia. Ahmadiyah Lahore dengan Gerakan Ahmadiyah Indonesia (GAI) yang berpusat di Daerah Istimewa Yogyakarta didirikan tahun 1928, dan Ahmadiyah Qadian diwakili organisasi Jama'ah Ahmadiyah Indonesia (JAI) yang terbentuk tahun 1932 dan berpusat di Parung Bogor.

GAI sebagaimana gerakan Ahmadiyah memiliki pemikiran, nilai, ekspektasi (pengetahuan kultural) yang ditransmisikan kepada para anggotanya atau masyarakat umumnya. Dalam konteks Ahmadiyah, terdapat konsepsi "Syiar Islam" yang menjadi jalan untuk menuju "Fathi Islam". Konsep "Syiar Islam" itu sendiri merupakan bentuk transmisi pengetahuan GAI. Syiar Islam GAI dilakukan salah satunya melalui kegiatan Perguruan Islam Republik Indonesia (PIRI). Sebagaimana disebutkan dalam Anggaran Rumah Tangga GAI bahwa PIRI merupakan sarana dan wahana pembentukan kader GAI.

Apakah yayasan PIRI merupakan bagian dari GAI dan terdapat upaya transmisi pengetahuan GAI di PIRI sebagaimana diduga oleh berbagai kalangan. Atau PIRI sebagai sebuah yayasan murni yang menyelenggarakan beragam kegiatan bidang sosial (termasuk penyelenggaraan pendidikan formal) dan keagamaan (termasuk melaksanakan syiar

${ }^{3}$ Pada tanggal 13 Januari 2012, Gerakan Ahmadiyah Indonesia (GAI) yang sedang menyelenggarakan Pengajian Tahunan Nasional di kampus PIRI Baciro Yogyakarta didatangi para pengunjuk rasa dari beberapa elemen masyarakat yang tergabung dalam Front Jihad Islam (FJI) Daerah Istimewa Yogyakarta. Lihat Yusuf Asry, 2013, Laporan Penelitian Gerakan Ahmadiyah Indonesia (GAI) Baciro Yogyakarta, Puslitbang Kehidupan Keagamaan Badan Litbang dan Diklat Kementerian Agama. 
keagamaan) yang tidak memiliki kaitan lagi dengan GAI. Untuk itulah perlu dilakukan penelitian eksistensi PIRI dalam kaitannya dengan transmisi pengetahuan GAI.

Penelitian bertujuan untuk mencari jawaban sekaligus mengklarifikasi posisi PIRI dalam kaitannya dengan transmisi pengetahuan GAI.Secara khusus, penelitian bertujuan untuk mendeskripsikan hubungan antara PIRI dan GAI, dan transmisi pengetahuan GAI di PIRI.

Penelitian ini dapat berguna dalam dua h. pertama, secara akademik bisa melengkapi kajian-kajian yang sudah ada dan memperkaya pengetahuan tentang pendidikan di PIRI secara khusus dan transmisi pengetahuan GAI secara umum. Kedua, secara praktis penelitian ini menjadi bahan rujukan dan pertimbangan dalam merumuskan kebijakan dalam meningkatkan akses layanan dan kualitas pendidikan Islam pada PIRI.

\section{Kerangka Konseptual}

\section{Transmisi Pengetahuan}

Membicarakan konsep "transmisi pengetahuan" melibatkan konsep "knowing" dan "learning". Manusia bergantung kepada bentuk pembelajaran yang kompleks dan luas. Tanpa masa pemeriharaan pasca kelahiran dan mendapatkan pengetahuan, seorang manusia tidak mampu mempertahankan biologinya. Hal itu dapat dikatakan bahwa manusia hidup dalam sebuah "information gap". Antara apa yang tubuh katakan kepada kita dengan apa yang seharusnya kita tahu agar secara efektif mengatasi lingkungan kita, terdapat sebuah ruang yang harus kita isi dengan informasi yang tersedia melalui kultur kelompok dimana kita lahir dan tumbuh. Ide, nilai, emosi, prilaku, dan persepsi merupakan hasil kultural dimana terkonstruksikan dalam merespon pengalaman sosial kita. ${ }^{4}$

${ }^{4}$ Judith Friedman Hansen, 1979, Sociocultural Perspectives on Human Learning: An Introduction
Untuk menghidupkan secara terus menerus hubungan yang terorganisir seluruh anggota komunitas, anggota baru harus mendapatkan kemampuan prilaku dan pengetahuan yang diperlukan untuk memutuskan kapan dan dimana menggunakan pengetahuan tersebut. Pengetahuan kultural dapat disederhanakan sebagai "resep pengetahuan" (recipe knowledge), misalnya, apa yang anggota harus tahu untuk berbuat dan bertindak dalam kehidupan keseharian. Pengetahuan kultural juga termasuk ideide tentang tabiat manusia dan kedudukan manusia dalam lingkungan sosial, nilai-nilai, kepercayaan tentang waktu dan sebagainya. Pengetahuan macam ini secara langsung mungkin atau tidak mungkin mempengaruhi prilaku para anggota atau anggota baru, tetapi "transmisi pengetahuan" menjadi penting dalam menjaga keberlangsungan kultural dari satu generasi kepada generasi berikutnya. ${ }^{5}$

Dalam seluruh masyarakat, pengetahuan kultural disebarkan secara berbeda di antara anggotanya. Bersama dengan pengaruh individu, faktor-faktor struktural dalam organisasi sosial memainkan peran yang penting. Persediaan pengetahuan (stocks of knowledge) berbeda dalam beberapa tingkatan antara laki-laki dan perempuan, muda dan tua. Sepanjang kekuasaan, kekayaan, pengaruh dan prestise didistribusikan secara tidak sama, maka orang akan berbeda dalam mendapatkan dan mengontrol pengetahuan dalam berbagai cara. Konsekuensinya, ide-ide dan nilai-nilai mereka mengenai persediaan pengetahuan kemungkinan berbeda.

Dalam pengertian yang luas, transmisi pengetahuan dapat digambarkan sebagai sebuah bentuk sosialisasi (socialization) dan enkulturasi (enculturation). Sosialisasi adalah proses-proses dimana seorang individu terintegrasi kepada sebuah kelompok sosial. Sementara enkulturasi merupakan proses-

To Educational Anthropology, Prentice Hall, INC., Englewood, N.J., h. 3

${ }^{5}$ Ibid., h. 25 
proses yang mana seorang individu anggota kelompok sosial memperoleh "kebiasaan dan pengetahuan" dari kelompok sosial tersebut. Proses-proses enkulturasi merupakan alat bagi transmisi semua pengetahuan kultural. Untuk menganalisa bentuk-bentuk transmisi ini mungkin mengambil dua konsep tambahan yang diperlukan, yaitu: pendidikan (education) dan persekolahan (schooling). Pendidikan dapat diartikan sebuah sub dari enculturation: sebuah upaya sistematik dan sengaja untuk mentransmisikan kemampuan dan pemahaman dan serangkaian pemikiran. Sedangkan persekolahan (schooling) dapat diartikan pelembagaan pendidikan (pendidikan yang terlembagakan).

\section{Transmisi Pengetahuan GAI}

Gerakan Ahmadiyah Indonesia (GAI) tidak bisa dilepaskan dari pergerakan Islam Ahmadiyah. Ahmadiyah adalah nama pergerakan Islam yang diberikan Hazrat Mirza Ghulam Ahmad (HMGA) dan diumumkan pada tahun 1900. Menurut HMGA, gerakan Ahmadiyah awalnya bernama "muslimin golongan Ahmadiyah". Nama ini diberikan kepada golongan tersebut karena Nabi suci mereka mempunyai dua nama, yang satu Muhammad, yang satu Ahmad. Nama Muhammad itu menunjukkan sifat jalalnya, yaitu keagungan dan kemuliannya. Sedang nama Ahmad menunjukkan jamalnya atau keindahannya. Pada 1905 HMGA mendirikan "Sadr Anjuman Ahmadiyah" sebagai badan yang dipersiapkan untuk meneruskan syiar Islam. $^{6}$

Ciri yang penting dari Gerakan Ahmadiyah adalah membela dan menyiarkan Islam menuju Fathi Islam (kemenangan Islam). Untuk tujuan syiar Islam dan hasilnya Fathi Islam, Ahmadiyah memandang bahwa Islam harus

${ }^{6}$ Nanang RI Iskandar. 2008. Dasa Windu Gerakan Ahmadiyah Indonesia 1928-2008. Jakarta: Darul Kutubil Islamiyah, h. 6-7. dihidangkan dalam bentuk yang sebenarnya. Karena itu Ahmadiyah memandang:

Islam sebagai agama yang hidup. Bagi Ahmadiyah, Islam adalah agama fitrah dan manusia menurut kodratnya dengan sendirinya tertarik kepada penciptaNya. Islam adalah agama fitrah manusia, agama yang bersahaja, sepi dari segala kesulitan upacara agama. Ahmadiyah memandang bahwa Islam adalah agama rasional yang dapat mendorong kepada pandangan hidup yang ilmiah. Islam adalah agama yang berpandangan luas dan toleran. Bagi Ahmadiyah, Islam adalah agama kemajuan. Islam adalah agama persatuan dan persaudaraan. Ahmadiyah memandang Islam telah memberi pengertian baru tentang agama, lalu dihubungkan dengan kegiatan manusia sehari-hari dan selanjutnya menjadi sumber daya kehidupan manusia. ${ }^{7}$

Kutipan di atas menegaskan bahwa Islam yang dipahami GAI adalah Islam yang disesuaikan dengan perubahan zaman. Implementasi dari pemahaman tentang Islam itu adalah sikap dan prilaku damai yang selalu berupaya untuk perbaikan masyarakat (tajdid). Karena itu, Gibb memasukkan Hazrat Mirza Ghulam Ahmad (HMGA) ke dalam gerakan intelektual. Sebagaimana pemikir Islam lainnya, HMGA berusaha memperbaiki keadaan umat Islam India melalui perubahan pola pikir dalam memahami agama Islam yang disesuaikan konteks zaman. ${ }^{8}$

Gerakan syiar Islam Ahmadiyah dilakukan dengan cara: penerbitan buku, penerbitan brosur, silaturahmi, surat menyurat, dan bai'at. Dari kelima kegiatan tersebut, inti kegiatan syiar Islam adalah kegiatan informasi dengan mengeratkan komunikasi antar sesama muslim untuk menciptakan ukhuwah islamiyah yang teguh dan bersama-sama membela dan

${ }^{7}$ Maulana Muhammad Ali. 2006. "Pengertian Hakiki Gerakan Ahmadiyah”. dalam Studi Islam. Volume 1 Nomor 1 Agustus, h. 53 dan 61

${ }^{8}$ Lihat kata pengantar Azyumardi Azra dalam Iskandar Zulkarnain. 2011. Gerakan Ahmadiyah di Indonesia, Yogyakarta, LKIS, h. Ix-x 
mempertahankan Islam dari serangan dan fitnah golongan-golongan yang membenci Islam. Selain itu, syiar Islam berupaya untuk meningkatkan harkat dan martabat Islam dengan membetulkan pengertianpengertian Islam yang salah akibat informasi mengenai Islam yang dijelaskan oleh orang yang bukan pemeluk Islam, atau pengertianpengertian Islam yang sengaja telah diubah atau diselewengkan oleh para pembenci Islam sehingga menyudutkan umat Islam. ${ }^{9}$

Penjabaran pelaksanaan perjuangan syiar Islam ditegaskan oleh Maulana Muhammad Ali, Sekretaris HMGA dalam 6 pedoman misi perjuangan syiar Islam Ahmadiyah, yakni: pertama, tujuan hidup kita adalah mensyiarkan agama Islam (the aim of our live is the propagation of Islam). Kedua, mengorbankan diri dan harta milik pribadi demi tujuan ini (to make sacrifices of one's person and possesions for this end). Ketiga, mempelajari Islam dan sejarahnya, dan juga keyakinan-keyakinan lainnya (to learn about Islam and its history, and about other faiths). Keempat, mengikuti ajaran syariat Islam dan menghormati lembaga-lembaga Islam lainnya. Kelima, memperlihatkan toleransi dan berlapang dada dalam penyiaran Islam, dan mencintai kaum muslim (to show tolerance and broad-mindedness in ther propagation of Islam, and to have love for Muslims). Keenam, menghormati dan memuliakan pelayanan Islam (to respect and honor the service of Islam). ${ }^{10}$

GAI memiliki perjuangan yang sama dengan Ahmadiyah Anjuman Isha'ati Islam (AAII) yang berpusat di Lahore, yakni: Syiar Islam demi mencapai Fathi Islam. Syiar Islam dalam konsepsi modernnya dapat dikatakan sebagai transmisi pengetahuan. Kata "syiar" dapat disejajarkan dengan "transmisi", dan kata "Islam" mengandung pengetahuan, nilai, ajaran, dan doktrin.

Bagaimana pengetahuan tentang keberislaman dalam menuju Fathi Islam dengan 6

\footnotetext{
${ }^{9}$ Nanang RI Iskandar, Op.Cit., h. 8.

${ }^{10}$ Maulana Muhammad Ali, Op.Cit., h. 8-9
}

pedoman GAI tersebut ditransmisikan atau disyiarkan. Dengan kata lain, bagaimana sosialisasi dan enkulturasi pengetahuan keberislaman GAI? Metode transmisi pengetahuan GAI dilakukan melalui: penerbitan, silaturahmi (termasuk PIRI dengan pendidikan model sekolah), dan pembaiatan.

Pertama, penerbit Darul Kutubil Islamiyah. Periode awal setelah GAI terbentuk, paham GAI ditransmisikan melalui penerbitan terjemahan buku-buku dan penerjemaham The Holy Qur'an. ${ }^{11}$ Pada bulan Desember 1938, GAI menerbitkan buku terjemahan bahasa Belanda De Religie van den Islam, karya Maulana Muhammad Ali. Pada periode awal GAI juga diterjemahkan Quran Suci Jarwa Jarwi. ${ }^{12}$ Dalam muktamar GAI tahun 1958, antara lain diputuskan bahwa GAI memandang perlu membentuk Badan Penerbitan yang dinamakan Darul Kutubil Islamiyah (DKI). ${ }^{13}$ Pada tahun 1976, DKI menjadi yayasan. Karena mengikuti undang-undang Yayasan, Darul Kutubil Islamiyah menjadi CV Darul Kutubil Islamiyah. ${ }^{14}$ Sampai penelitian ini dilakukan, CV Darul Kutubil Islamiyah masih eksis dengan penerbitannya. ${ }^{15}$

Kedua, kegiatan silaturahmi. Silaturahmi dalam pandangan GAI bukan sekedar saling kunjung antar sesama anggota. Silaturahmi diartikan secara luas yakni saling berinteraksi dengan baik dan saling mengingatkan agar selalu meningkatkan iman dan taqwa. Silaturahmi ini dilakukan dalam tiga bentuk kegiatan, yaitu: kegiatan majlis taklim, pengajian tahunan dan kegiatan muktamar. Menurut Nanang RI Iskandar, PIRI merupakan salah satu bentuk kegiatan dari silaturahmi. Dalam konteks Syiar Islam dan Fathi Islam

${ }^{11}$ S. Ali Yasir dan Yatiman AS. 1989. 100 Tahun Ahmadiyah, 60 Tahun Gerakan Ahmadiyah Lahore Indonesia, Media Komunikasi No.02, Pedoman Besar GAI Bagian Tabligh dan Tarbiyah, h. 37

${ }^{12}$ S.Ali Yasir dan Yatiman., h. 39

${ }^{13}$ S. Ali Yasir dan Yatiman., h. 42-44

${ }^{14}$ Nanang RI Iskandar, Op.Cit., h. 93-94

${ }_{15}$ Observasi tim peneliti ke kantor penerbit Darul Kutubil Islamiyah di Jalan Kesehatan IX No 12 Jakarta Pusat, tanggal 25 Oktober 2013. 
Ahmadiyah dan GAI, PIRI dimaksudkan untuk membentuk kader GAI. Kegiatan PIRI lebih berkembang dibanding kegiatan GAI sendiri. Kegiatan kaderisasi yang sejak awal menjadi pemikiran dari Djoyosugito dan Moch.Husni juga diberikan kepada guru-guru PIRI yang berpotensi memberi bekal untuk siswa PIRI dalam mengenalkan Islam yang ditajdid atau Islam dengan pengertian-pengertian yang mampu untuk menjawab tantangan-tantangan zaman. ${ }^{16}$ PIRI dapat dikatakan sebagai metode transmisi pengetahuan GAI yang khas pergerakan Ahmadiyah Indonesia. Namun demikian, PIRI dan pendidikan serta lembaga sekolahnya dapat dilihat sebagai bentuk enkulturasi pengetahuan GAI.

Ketiga, kegiatan bai' at. Peristiwa bai' at pada masa Nabi Muhammad dicontoh oleh Hazrat Mirza Ghulam Ahmad dengan memberikan 10 ungkapan janji yang diucapkan waktu bai'at. ${ }^{17}$ Pelaksanaan bai'at sebagai berikut: 1 ) mengucapkan kalimat syahadat, 2) mengakui HMGZ sebagai mujaddid, al-Masih dan alMahdi, dan 3) diikuti dengan mengucapkanjanji sepuluh. Janji Sepuluh adalah ikatan perjanjian antara diri yang bersangkutan dengan Masih Yang Dijanjikan, berdasarkan hati yang telah menyatu dalam kalimat syahadat. Bai'at adalah upaya jalan kemenangan (Fathi) Islam yang terakhir. Setelah menjadi anggota GAI

${ }^{16}$ Nanang RI Iskanadar. Op.Cit., h. 122-123

${ }^{17}$ Kesepuluh janji itu adalah: 1) selama hidup tidak akan berbuat syirik, 2) akan menyingkirkan segala macam kejahatan, 3) akan tekun menjalankan shalat 5 waktu sesuai perintah Nabi Muhammad Saw dan sekuatnya akan menjalankan shalat tahajud, bershalawat, beristighfar, bertakbir, bertahmid dan bersyukur atas segala karunia nikmat Allah SWT, 4) tidak akan menyakiti sesama manusia, 5) akan tetap setia kepada Allah SWT dalam segala apapun juga, 6) akan menjauhkan diri dari kelakuan buruk, ajakan hawa nafsu dan tetap setia kepada Quran suci dan sunnah Nabi sebagai pedoman hidup, 7) tidak takabur dan menjalani hidup dengan rendah hati, 8) menjunjung tinggi kehormatan agama Islam melebihi harta, tahta dan anak saudara,9) mencintai sesama manusia karena Allah SWT dan bekerjasama untuk kesejahteraan umat manusia, 10) menaati perjanjian ini sampai mati, dan dengan keikhlasan selalu akan meneguhkan perjanjian ini lebih kuat dari ikatan lainlainnya. (ahmadi), seorang anggota GAI otomatis menjadi seorang muballigh.

Menurut Mulyono, setiap anggota GAI sebaiknya memiliki perencanaan terhadap aktivitas tablighnya. Pertama-pertama menentukan target sasaran dan target hasil. Target sasaran dimulai dari orang-orang yang paling dekat hingga yang paling jauh, yaitu: mulai dari isteri/suami, kemudian anak, anggota keluarga lain, komunitas (lingkungan masyarakat tempat tinggal, lingkungan kerja, lingkungan pergaulan lain), sampai ke masyarakat umum. Sedangkan target hasil, dimulai dari yang paling sederhana hingga yang tertinggi, yakni: (1) tidak memusuhi Ahmadiyah, tidak bersikap fobi, tidak apriori, tidak antipati, tidak skeptis, dsb, (2) memahami Ahmadiyah dan mampu menjelaskan kepada orang lain, (3) simpati terhadap Ahmadiyah Lahore, dan (4) Bai'at. ${ }^{18}$

Boleh jadi tidak setiap anggota Ahmadiyah mampu mencapai target sasaran tertinggi (masyarakat umum) dengan target hasil tertinggi pula (bai'at). Target sasaran terendah (isteri/suami) dan target hasil terendah (tidak memusuhi Ahmadiyah) pun, jika hal itu diniati secara benar, maka akan memiliki makna yang sangat penting bagi program sosialisasi dan kaderisasi GAI. ${ }^{19}$

\section{Metode Penelitian}

Berdasarkan tujuannya, penelitian ini lebih bersifat deskriptif. Dilihat dari metode pendekatan yang digunakan, penelitian ini menggunakan pendekatan kualitatif. Sedangkan ditinjau dari cakupan atau besaran sumber data yang dijadikan sebagai subjek penelitian dapat dikategorikan penelitian kasus.

${ }^{18}$ Lihat Mulyono. 2006. "Sosialisasi dan Kaderisasi GAI Sebuah Keniscayaan”. dalam Kaderisasi GAI, Reaktualisasi Dakwah Islam dengan Salam, Yogyakarta, Tim Naskah Jalsah Salanah GAI 2006, h. 42

${ }^{19}$ Ibid., h. 42-43 
Metode pengumpulan data mencakup sumber data, instrumen pengumpulan data, dan prosedur pengumpulan data. Pengumpulan data dilakukan dengan menggunakan beberapa teknik: pertama, studi literatur yang digunakan untuk mengumpulkan konsep, teori pendukung dan referensi yang ada kaitannya dengan masalah transmisi pengetahuan, transmisi pengetahuan GAI, dan PIRI. Kedua, wawancara yang digunakan untuk memperoleh data dari informan pengurus GAI, pengurus PIRI, pengurus Darul Kutubil Islamiyah, dan penyelenggara sekolah-sekolah PIRI. Ketiga, observasi ke sekolah-sekolah PIRI dan kantor GAI di Yogyakarta, dan penerbit Darul Kutubil Islamiyah di Jakarta. Observasi ini digunakan untuk memperoleh data pelaksanaan pendidikan di sekolah-sekolah PIRI, aktivitas GAI, dan aktivitas penerbitan.

Sebelum melakukan analisis data terhadap data yang terkumpul, peneliti melakukan proses validasi dan pemeriksaan keabsahan data. Data yang telah dikumpulkan dianalisis dengan menggunakan analisis kasus. Data yang sudah terkumpul dilakukan: reduksi data, penyajian data, dan menarik kesimpulan. Proses analisis data kualitatif berlangsung selama dan pasca pengumpulan data. Proses analisis data kualitatif tidak menjadi kaku oleh batasan-batasan tersebut. Komponenkomponen analisis data secara interaktif saling berhubungan selama dan sesudah pengumpulan data.

\section{HASIL DAN PEMBAHASAN}

\section{PIRI dan Hubungannya dengan GAI}

Muktamar GAI tahun 1947 di Purwokerto menghasilkan salah satu keputusan untuk mendirikan Perguruan Islam yang diasuh oleh GAI. Pengurus Perguruan Islam dibentuk dengan Ali Murni sebagai ketua, dan Supratolo, S.Citrosancoko dan Ibu Djoyosugito sebagai anggota. Perguruan ini dinamakan Perguruan Islam Republik Indonesia (PIRI). Kegiatan PIRI inilah dalam masa-masa kemerdekaan yang berjalan dalam organisasi GAI. ${ }^{20}$

Tujuan awal PIRI adalah membentuk kader GAI dengan sistem pondok. Tetapi dalam pelaksanaannya berbentuk sekolah-sekolah. Karena itu, GAI melihat perlu merubah status PIRI menjadi bukan bagian GAI melainkan berstatus otonom dengan bentuk yayasan. Sebagai ketua yayasan PIRI diangkat Ibu Djoyosugito. Dengan demikian PIRI memiliki kebebasan untuk mengatur rumah tangganya sendiri, sekalipun dalam hal pemeliharaan ruhani PIRI tetap bersumber pada GAI. ${ }^{21}$

PIRI mengalami pasang surut dalam hubungan organisatoris dengan GAI. Muktamar GAI pada 25-28 Desember 1958 di Yogyakarta, memutuskan: (a) PIRI tidak lagi menjadi bagian dari GAI, dan (b) menyerahkan tugas penyelesaian PIRI menjadi badan hukum berbentuk Yayasan kepada R.Haji Minhadjurrahman Djojosugito dalam kedudukan sebagai pendiri. Sejak keluar keputusan muktamar 1958 dan akte notaris no.3 tanggal 3-2-1959, PIRI menjadi organisasi otonomi, bersifat independent dan bukan bagian dari GAI.

Sejak ketua umum GAI dipimpin oleh Prof. Dr. Ahmad Muhammad (1979-1990), PIRI kembali dibawah naungan GAI. Berdasarkan akte Yayasan PIRI tertanggal 16 April 1984, yayasan PIRI memiliki Badan Pemangku Azas yang diangkat dan diberhentikan oleh Pedoman Besar Gerakan Ahmadiyah Lahore Indonesia. Berdasarkan akte Yayasan PIRI tertanggal 6 Januari 1998 yang berlaku sampai saat ini secara ekplisit tidak mencantumkan organ Yayasan dari Pedoman Besar Gerakan Ahmadiyah Indonesia.

Saat ini PIRI diketuai oleh Dr.Ir.H.Iwan Yusuf B Lelana, MSc dan sebagai ketua pembinanya adalah Prof. Ir. H. F. Ahmadi Djoyosugito. Dalam Personalia Pedoman Besar GAI Periode Tahun 2009-2014, Prof. Ir. H. F.

\footnotetext{
${ }^{20}$ S. Ali Yasir dan Yatiman AS, Op.Cit., h. 40

${ }^{21}$ Ibid., h. 42
} 
Ahmadi Djoyosugito adalah ketua umum GAI, dan Dr.Ir.H.Iwan Yusuf B Lelana, MSc sebagai ketua bidang pendidikan dan hubungan luar negeri GAI. Sebagian pengurus PIRI adalah pengurus GAI. ${ }^{22}$

PIRI berasaskan Qur'an Suci dan Sunnah Nabi dengan tiga pegangan pokoknya, yaitu:

(a) Qur'an Suci merupakan azas dan petunjuk dari Allah yang Maha Suci dan Maha Agung, bagi kehidupan dan penghidupan seluruh umat manusia, yang terakhir dan sempurna, (b) keyakinan bahwa Nabi Suci Muhammad saw adalah Nabi yang terakhir, sempurna, suri tauladan yang terbaik bagi seluruh umat manusia dalam macam keadaan dan masa, dan sesudah beliau saw tidak ada Nabi yang akan datang, baik Nabi lama maupun Nabi baru, (c) pengakuan, bahwa sesudah wafatnya Nabi Suci Muhammad saw akan datang Mujaddid-Mujaddid (pembaharupembaharu) pada tiap-tiap permulaan abad, dan Hazrat Mirza Ghulam Ahmad adalah Mujaddid pada abad ke-14 Hijriyah. ${ }^{23}$

Menurut Ali Yasir, dua asas dan tiga pegangan teguh tersebut juga merupakan asas dan pegangan teguh GAI. Antara PIRI dan GAI seperti dua sisi dari sekeping mata uang. Tujuan dan ide-ide pembaharuan dalam Islam oleh Hazrat Mirza Ghulam Ahmad (HMGA) dinterpretasikan oleh sekretarisnya, Maulana Muhammad Ali (w.1955) dan dikembangakan oleh R.H. Minhadjurrahman Djojosugito sebagai pendiri GAI sekaligus pemerakarsa berdirinya PIRI. ${ }^{24}$

Untuk mencapai tujuan sebagai pengemban visi dan misi GAI, pendidikan PIRI diformulasikan sebagai berikut: (a) Sekolah TK, dengan maksud menanamkan

${ }^{22}$ Dokumen Personalia Pedoman Besar Gerakan Ahmadiyah Indonesia Periode Tahun 2009-2014 yang dikeluarkan Gerakan Ahmadiyah Indonesia (Ahmadiyya Anjuman Isha'ati Lahore).

${ }^{23}$ S.Ali Yasir. 2013. Yayasan PIRI: Pengembang Misi Pendidikan Islam dalam Perspektif GAI, h. 2, makalah tidak diterbitkan.

${ }^{24}$ Ibid., h. 3 jiwa tauhid dalam rangka pertumbuhan rohani dan jasmani sebelum masuk SD, (b) Sekolah Dasar, menuntun pertumbuhan jiwa tauhid dalam rangka pertumbuhan rohani dan jasmani, bakat, kecakapan dan ketangkasan lahir batin anak-anak, (c) Sekolah Menengah Umum, Kejuruan dan Teknologi dengan maksud membimbing jiwa tauhid dalam rangka melanjutkan pengajaran di sekolah dasar ke arah tenaga ahli dalam pelbagai lapangan khusus sesuai dengan bakat dan keperluan masyarakat, dan/atau persiapannya ke Sekolah Tinggi sehingga tercapai citacita hidup, dan (d) Sekolah Tinggi dengan maksud memperkuat pertumbuhan jiwa tauhid sebagai kelanjutan tegaknya kedaulatan ilahi, sehingga para mahasiswa menjadi manusia yang di dalam masyarakat dapat memberikan pimpinan ataupun kemajuan hidup masyarakat manapun, kemajuan ilmu pengetahuan yang bermanfaat dan tidak merusak atau merugikan kemanusiaan. $^{25}$

Formula pendidikan di PIRI dalam berbagai jenjangnya yang berdasarkan "jiwa tauhid" menunjukkan ruh GAI menjadi basis penyelenggaraan pendidikan di PIRI. Ruh GAI dalam penyelenggaraan pendidikan di sekolahsekolah PIRI mempengaruhi rekruitmen dan pengangkatan posisi kepala sekolah. Dari 11 kepala sekolah, sebanyak 8 atau (73\%) kepala sekolah adalah GAI. Bahkan 3 dari 8 kepala sekolah tersebut berstatus sebagai pengurus GAI.

Bagaimana dengan guru-guru di sekolahsekolah PIRI. Dari jumlah 279 guru yang mengajar di 11 sekolah PIRI yang berada di DIY, sebanyak 98 orang (35\%) merupakan anggota GAI, bahkan dari 98 orang itu sebanyak 8 orang $(8,2 \%)$ adalah pengurus GAI. Namun demikian, dari jumlah 279 guru, sebagian besar 181 orang (65\%) bukan anggota GAI. Ini artinya, orang yang ingin mengajar dan mengabdi di PIRI tidak harus anggota GAI.

\footnotetext{
${ }^{25}$ Ibid., h. 8
} 
Semua guru di sekolah-sekolah PIRI esensinya guru agama. Tidak dibedakan atau dipisahkan antara guru-guru al-'ulumunaqliyah dengan guru-guru al-'ulumul ijtihadiyah atau al'ulumul hikmiyyah, sebab keduanya sama-sama bersumber dari Allah. Perbedaannya adalah al-ulumunaqliyah bersumberkan firman dalam bentuk wahyu yang disampaikan malaikat jibril kepada para Nabi dari berbagai bangsa di dunia sejak Nabi Adam sampai Nabi Muhammad. Mereka adalah, dalam pandangan PIRI, para pendidik sejati umat manusia. Sedangkan al'ulumul 'aqliyah atau ijtihadiyah juga bersumber dari Allah kepada alam semesta sebagai karyaNya. ${ }^{26}$

Pada hakekatnya semua guru di sekolahsekolah PIRI berperan sebagai pendidik. Pendidik dikonsepsikan sebagai pengemban "amanah" risalah islamiyah yang sekaligus sebagai pengemban "imamah". Untuk itu, semua guru menjadi teladan terutama menjadi pembina akhlakul karimah dalam mengupayakan terwujudnya cita-cita dan tujuan pendidikan agama Islam.

Guru sebagai pendidik adalah orang yang mampu menyediakan dirinya untuk memikul tangggung jawab sebagian tugas pendidikan orangtua terhadap anak-anaknya, sehingga guru harus mampu menjadi "suri tauladan" di manapun dan kapanpun, baik suri tauladan bagi siswa maupun masyarakat lingkungannya baik berupa pemikiran, sikap maupun tindakannya. Untuk itu, guru sebagai pendidik di PIRI minimal harus memiliki kompetensi keperibadian, yaitu: taat menjalankan perintah Tuhan, berjiwa pengabdian yang tinggi, mempunyai sifat ikhlas untuk beramal shaleh, hatinya senantiasa terikat hanya kepada Allah, aktif beribadah, bertangggung jawab, cinta profesi, memiliki sifat kasih-sayang, yakin dan teguh pada kebenaran Islam.

Peran pendidik cenderung menjadi sentral dalam proses pembelajaran di sekolah-sekolah PIRI. Hal ini sesuai dengan semboyan Ki Hadjar

\footnotetext{
${ }^{26}$ S.Ali Yasir, Op.Cit., h. 8-9.
}

Dewantara "ing ngarso sung tulodo, ing madya mangun karso, tut wuri handayani". Karena itu, ungkapan bahwa "undzur ma qala, wa la tandzur man qala" tidak diterima begitu saja dalam konsepsi GAI dan praktek di PIRI, dengan alasan bahwa perintah Allah kepada Nabi Muhammad SAW yang menyatakan, "jika kamu mencintai Allah, maka ikutilah aku".

\section{Transmisi Pengetahuan GAI dan Pelaksanaan Pendidikan Agama Islam di PIRI}

Transmisi pengetahuan GAI melalui penerbitan, silaturahmi dan pembaiatan tidak terlalu dominan di PIRI. Meskipun demikian transmisi pengetahuan GAI melalui tiga metode tersebut dapat dilihat di PIRI dari indikasiindikasi berikut. Produk-produk penerbitan Darul Kutubil Islamiyah di Yogyakarta dan Jakarta dapat ditemukan di perpustakaan kantor GAI yang ruangannya satu lokasi dengan kampus PIRI di Baciro. Aktivitas silaturahmi seperti kegiatan majlis taklim dilaksanakan di kampus PIRI. Aktivitas silaturahmi lain yaitu kegiatan "Jalsah Salanah" pada 13 Januari 2012 yang pernah menjadi pro-kontra juga diadakan di kampus PIRI. Kegiatan pembaiatan yang merupakan prasyarat menjadi seorang anggota GAI (ahmadi) dapat dikatakan tidak nampak di PIRI. Aktivitas tabhlig dilakukan hanya oleh mubaligh-mubaligh ahmadi yang sudah ada.

Sebaliknya institusi PIRI sendiri dengan segala aktivitas sekolah-sekolahnya menjadi cara dan instrumen dominan dalam transmisi pengetahuan GAI. Metode transmisi pengetahuan GAI yang paling terlihat di PIRI adalah pelaksanaan pendidikan agama Islam (PAI) di sekolah-sekolah PIRI. Uraian berikut adalah deskripsi tentang transmisi pengetahuan GAI dalam pelaksanaan PAI di PIRI yang meliputi: dasar, visi, misi, guru, dan materi pendidikan agama Islam.

Dasar Pendidikan Agama Islam dalam perspektif GAI sebagaimana diterapkan di 
sekolah-sekolah PIRI adalah berdasarkan kepada Kitab Suci al-Qur an dan Sunnah Nabi, dengan visi dan misi sebagai berikut: ${ }^{27}$ Visi PAI adalah terbentuknya peserta didik yang islami dan berjiwa pembaharu dalam rangka untuk mewujudkan masyarakat madani.

Sedangkan misi PAI adalah: pertama, menyelenggarakan PAI berdasarkan kurikulum Yayasan PIRI dengan mengakomodasi kurikulum pemerintah. Kedua, menyelenggarakan PAI dengan mengedepankan kualitas pendidikan, pembentukan akhlak mulia, sikap toleran, berjiwa sosial dan berwawasan lingkungan. Ketiga, mengembangkan PAI berbasis tafaqquh fi al-din (pemahaman agama Islam yang sesuai dengan al-Qur'an dan as-Sunnah) untuk membentuk peserta didik yang berwawasan ukhuwah Islamiyah, wathaniyyah dan insaniyyah. Keempat, meningkatkan menejerial dan tata kola PAI berdasarkan prinsip professional, akuntabiltas, transparansi dan efisiensi. Kelima, mengembangkan TK/Sekolah/ Lembaga Pendidikan agar mampu mewujudkan generasi yang unggul dalam Iptek dan Imtaq. Keenam, mengembangkan potensi peserta didik pada ranah kognitif, afektif dan psikomotorik secara khusus dalam hal shalat dan al Qur an. Ketujuh, membudayakan karakter islami, antara lain: jujur, amanah, cerdas, kerja keras, disiplin, istiqamah dan ikhlas.

Visi dan misi di atas, mengambarkan bahwa konsep PAI dalam persepektif GAI sebenarnya tidak jauh berbeda dengan konsep PAI pada sekolah umumnya, yaitu berdasarkan al-Qur an dan as-Sunnah. Perbedaannya dalam hal, misalnya visi peserta didik "yang berjiwa pembaharu". Jiwa pembaharu ini sesuai dengan salah satu tiga pegangan teguh PIRI dan GAI.

Bagaimana visi dan misi PAI ini diterjemahkan ke dalam materi-materi pendidikan

${ }^{27}$ Visi dan misi bersumber dari dokumen Surat Keputusan Badan Pengurus Yayasan PIRI Nomor: 085/A/ PP/2013 Tentang VISI-MISI Pendidikan Agama Islam (PAI) Yayasan PIRI, tahun 2013-2018 yang ditetepkan di Yogyakarta pada tgl. 1 Maret 2013 dan ditandatangani oleh Ketua Umum PIRI DR. Ir. H. Iwan Yusuf BL, M. Sc. agama Islam di sekolah-sekolah PIRI. Yayasan PIRI membagi mata pelajaran pendidikan agama Islam ke dalam beberapa aspek. Untuk tingkat SMP dibagi dalam 7 (tujuh) aspek atau sub bidang studi, yakni: 1) Al-Qur'an, 2) praktik ibadah, 3) ilmu aqaid, 4) ilmu fiqih, 5) pendidikan akhlak, 6) tarikh Islam (mengikuti jejak orang-orang tulus), dan 7) pengantar pembaharuan dalam Islam (Ke-PIRI-an). Sedangkan untuk tingkat SMA/SMK dibagi dalam aspek atau sub bidang studi, yakni: 1) AlQur'an dan Praktek Ibadah, 2) Aqidah Islam, 3) Fiqih Islam, 4) pendidikan Akhlak, 5) Gerakan Pembaharuan dalam Islam (At-Tajdid fil Islam) atau ke-PIRI-an, dan 6) Tarikh Islam (mengenal nabi muhammad saw melalui Nubuat).

Kekhasan yang nampak dari aspek-aspek mata pelajaran pendidikan agama Islam adalah materi ke-PIRI-an. Materi ke-PIRI-an untuk tingkat SMP adalah materi "pengantar pembaharuan dalam Islam", dan untuk tingkat SMA/SMK adalah materi "Gerakan Pembaharuan dalam Islam". ${ }^{28}$

Materi ke-PIRI-an untuk tingkat SMP kelas 1 dan kelas 2 berisikan ke-GAI-an yang meliputi: AD/ART, keanggotaan, sikap, dan iktikad GAI. Dalam tingkat ini, siswa diajarkan tentang organisasi GAI. Selanjutnya, siswa diberikan materi "Pengantar Pembaharuan dalam Islam" di kelas 3. Materi ini terbagi kepada dua bab, yakni bab "Ahmadiyah Anjuman Isha'ati Islam" dan bab "kesalahpahaman terhadap Ahmadiyah Lahore". Dalam bab Ahmadiyah Anjuman Isha'ati Islam dijelaskan tentang gerakan Ahmadiyah, perpecahan gerakan Ahmadiyah, dan Perbedaan Ahmadiyah Lahore dengan Ahmadiyah Qadian. Sedangkan dalam bab kesalahpahaman terhadap Ahmadiyah Lahore dijelaskan beberapa hal, yaitu: Muhadats, Wahyu Ilahi, Mujadid, Masih dan Mahdi, kenabian Zarathustra, Budha, dan

${ }^{28}$ S.Ali Yasir. 2010. Pendidikan Agama Islam untuk SMP Yayasan PIRI 1,2, dan 3. Yogyakarta: Pengurus Pusat Yayasan Perguruan Islam Republik Indonesia. Lihat juga buku Pendidikan Agama Islam untuk SMA/SMK Kelas 1,2 dan 3 yang juga diterbitkan Yayasan Perguruan Islam Republik Indonesia. 
Kong Fu Tse, Nasikh Mansukh, Nabi Adam, Jihad, Ketidakkekalan Neraka, Isra Mi'raj, Nabi Isa berbapak, wafatnya nabi Isa, serta cara menafsirkan Qur'an Suci.

Sedangkan materi ke-PIRI-an untuk SMA/ SMK disesuaikan dengan tingkatan kelasnya. Untuk kelas 1, diajarkan: perlunya lembaga kenabian, nabi Muhammad adalah kesudahan para nabi, penjagaan ilahi terhadap nubuat Muhammadi, dan Al-Masih dan Mahdi Yang dijanjikan. Setelah itu untuk kelas 2 diajarkan: kehidupan agama Islam, pembaharuan dalam Islam, dan Hazrat Mirza Ghulam Ahmad. Materi-materi lain yaitu: Islam Agama Fitrah, Kedudukan Qur'an Suci, Adam Manusia Pertama?, dan Nabi Isa adalah manusia biasa, diajarkan di kelas 3.

Mengapa pembaharuan menjadi topik sentral dalam pendidikan agama Islam di sekolah-sekolah PIRI. Menurut Ali Yasir, seorang mantan ketua umum GAI dan guru PAI, berkata:

Dalam al-Qur'an suci dan Sunnah, Allah dan Rasul Nya memberikan keterangan dan penjelasan tentang bagaimna cara memelihara dan menghidupkan agama Islam. Karena itu, al-Qur'an suci berulangkali menyuruh dan memerintahkan manusia mempergunakan akalnya. Namun, tidaklah berarti bahwa seluruh masalah agama dapat dicapai dengan akal sehat, sebab jika demikian, apakah gunanya Allah membangkitkan, mengangkat atau mengutus para Nabi (pada zaman dulu) dan para mujaddid pada setiap umat Islam yang dilanda kerusakan. Mengapa bukan orang pandai saja sebagai panutan umat manusia ke jalan yang benar. Jelaslah bahwa masalah agama itu ada pada wewenang Allah sendiri, bukan dibuat-buat atau ditentukan oleh umat manusia. Untuk itulah masalah “pembaharuan dalam Islam” (at-tajdid fil Islam), juga merupakan ketentuan dari Allah sendiri, sama sekali tidak direncanakan dan ditentukan oleh umat manusia, tapi kebanyakan manusia pada zamannya justru menentangnya. ${ }^{29}$

Lebih lanjut Ali Yasir mengatakan bahwa pada zaman sebelum Nabi suci Muhammad saw, setiap kali umat manusia dilanda atau ditimpa suatu kerusakan, Allah mengutus seorang Nabi untuk memperbaiki dan menghidupkan kembali agama Nya yang telah diturunkan ke dunia. Untuk itu, para nabi dan rasul silih berganti secara beruntun sejak Nabi Adam sampai kepada Nabi Muhammad sebagai nabi penutup. ${ }^{30}$ Berkaitan dengan itu, kata Ali Yasir, Allah SWT berjanji bahwa setiap kali umat Islam ditimpa kerusakan, maka Allah akan selalu mengutus seorang "pembaharu" (mujaddid) pada setiap permulaan abad. Para mujaddid yang dibangkitkan oleh Allah itulah yang mendapatkan amanah Allah untuk melaksanakan pembaharuan (tajdid) dalam Islam. ${ }^{31}$

\section{Keberagamaan Yang Inklusif-Dialogis: Pengalaman Guru Agama SMA PIRI I Yogyakarta}

Pendidikan agama Islam merupakan salah satu mata pelajaran di sekolah-sekolah PIRI. Uraian berikut saya fokuskan kepada pengalaman seorang guru agama di SMA I PIRI dalam pelaksanaan pendidikan agama. Menurut pengalaman salah seorang guru PAI, Anis Farikhatin, bahwa pendidikan agama masih banyak mengajarkan paham keagamaan yang eksklusif-teoritik-normatif. Pandangan inilah yang disinyalir memproduksi manusia yang tertutup, fanatis dan memandang golongan lain (tidak seakidah) sebagai musuh. Karena itu, menurut Farikhatin, diperlukan pendidikan agama yang inklusif-dialogis berwawasan multikultural, dimana fokusnya

${ }^{29}$ Wawancara dengan S. Ali Yasir di kampus PIRI, tanggal 19 Juli 2013

${ }^{30}$ Wawancara dengan S. Ali Yasir di kampus PIRI, tanggal 20 juli 2013

31 Wawancara dengan S. Ali Yasir di kampus PIRI,tanggal 20 Juli 2013 
adalah bukan semata-mata kemampuan ritual dan keyakinan tauhid, melainkan juga akhlak sosial dan kemanusiaan. ${ }^{32}$

Membangun keberagamaan inklusifdialogis di SMA I PIRI dilakukan dengan fokus kepada dua hal, yakni: guru dan proses pembelajaran. Guru didorong untuk membuka diri dengan Dian-Interfidei dan lembaga lain yang memfasilitasi guru-guru agama untuk mengembangkan nilai-nilai multikultural di sekolah. Interaksi itu melahirkan FKGA (forum komunikasi guru-guru agama lintas iman) pada tahun 2007. Setelah terbentuk, forum ini melakukan dialog dan silaturrahim ke berbagai tempat ibadah seperti vihara, sekolah seminari, kelentheng, Ashram Krishna, pondok pesantren dan lain-lain. Di tempat-tempat ibadah tersebut, mereka diperlihatkan berbagai ritual keagamaan. Dengan cara menyaksikan langsung beragam ritual keagamaan, melahirkan pemahaman bahwa dalam semua agama terdapat keyakinan dan pengalaman iman luar biasa yang sulit dirumuskan dengan logika.

Pemahaman ini menjadikan jalinan persaudaraan semakin terasa erat. Rasa saling percaya pun mulai terbangun. Pada tahap ini, menurut Farikhatin, ${ }^{33}$ para guru sudah memasuki tahapan dialog yang sangat jauh, mulai dari dialog sebagai sesama manusia dan sesama makhluk Tuhan (dialogue of heart), dialog untuk menegakkan nlai-nilai kehidupan kemanusiaan (dialogue of life), sampai dialog untuk memperbincangkan Tuhan dan manusia dalam kedamaian (dialogue of peace). Akhirnya, pengalaman ini menumbuhkan keberanian dan kepercayaan diri para guru agama untuk menintegrasikan nilai-nilai multikultur ke dalam pendidikan agama yang diampunya.

Setelah terbangun pemahaman yang demikian, guru agama mengimplementasikan kepada praktek pembelajaran pendidikan

${ }^{32}$ Anis Farikhatin. 2013. "Membangun Keberagamaan Inklusif-Dialogis di SMA PIRI I Yogyakarta". MAARIF Vol. 8, No.1-Juli, h. 111

${ }^{33}$ Ibid., h. 118-119 agama inklusif-dialogis yang ditunjukkan dengan tiga kata kunci yaitu: silaturrahim, dialog dan refleksi. Sehubungan dengan itu, langkah strategis yang dilakukan Farikhatin adalah: ${ }^{34}$ pertama, mengorientasikan pembelajaran pendidikan agama kepada substansi nilai (religiousity) bukan bertumpu pada belajar tentang agama (religion) yang cenderung material formal. Kedua, dari segi metodologis, menggunakan pendekatan pembelajaran orang dewasa (andragogis). Ketiga, menambah materi aktual yang terjadi dalam kehidupan peserta didik seperti kerisis lingkungan, ketidakadilan, narkoba, HIV/ AID, aborsi, free sex, rerorisme dan sebagainya. Keempat, bersinergi dengan lembaga lain seperti BKKBN, PKBI, Pengadilan Agama, BNN, Interfidei, KUA, Lembaga Pemasyarakatan, dan lain-lain. Juga berkolaborasi dengan guru bidang studi non-agama.

Hasil dari peroses pembelajaran pendidikan agama dalam bentuk pengalaman tersebut kemudian direfleksikan oleh guru dan siswa. Sebagaimana hasil refleksi Farikhatin, seperti diakuinya, bahwa silaturrahim dan dialog sebagai model pembelajaran inklusifdialogis humanis memberikan pemahaman bahwa:

Pengalaman adalah guru yang terbaik jika dimaknai sehingga mampu menjadi spirit hidup. Pengalaman menuntun seseorang menemukan makna dan kesadarannya. Belajar dari pengalaman merupakan proses mengubah pengetahuan agama yang kognitif menjadi makna dan nilai. Belajar dari pengalaman lebih humanis, karena menempatkan partisipan belajar sebagai subyek belajar. ${ }^{35}$

Selain refleksi guru, proses pembelajaran pendidikanagamadengan model keberagamaan inklusif-dialogis juga direfleksikan kepada siswa. Hasilnya adalah memberi pengaruh positif terhadap minat belajar siswa, perubahan

\footnotetext{
${ }^{34}$ Ibid., h. 120

${ }^{35}$ Ibid., h. 125
} 
dan pola pikir dan pemahaman siswa maupuan perubahan perilaku siswa.

Apa yang dipraktekkan dan dialami oleh Anis Farikhatin ini sesuai dengan apa yang divisikan oleh PIRI yaitu peserta didik "yang berjiwa pembaharu", dan dimisikan PIRI yaitu penyelenggaraan PAI dengan mengedepankan pembentukan akhlak mulia, sikap toleran, berjiwa sosial dan berwawasan lingkungan serta membentuk peserta didik yang berwawasan ukhuwah Islamiyah, wathaniyyah dan insaniyyah.

\section{PENUTUP}

\section{Kesimpulan}

Pertama, ada hubungan historis dan keruhanian, dan tidak ada hubungan organisatoris antara PIRI dan GAI. Secara historis, PIRI lahir dari rahim GAI yang bertujuan untuk membentuk kader GAI dengan sistem pendidikan sekolah. Secara keruhanian, penyelenggaraan PIRI tetap bersumber pada ruh GAI. Kegiatan pendidikan PIRI yang dijiwai oleh ruh GAI adalah: visi pendidikan PIRI sama dengan visi GAI yang memiliki pemikiran tajdid (pembaharuan) dan sebagian besar pengurus PIRI (ketua yayasan, kepala sekolah, guru PAI) adalah pengurus dan anggota GAI. Secara organisatoris, PIRI tidak menjadi bagian dari GAI. PIRI adalah sebuah yayasan dan GAI sebagai ormas Islam yang mana ormas GAI ini berbeda dengan jemaat Ahmadiyah Indonesia (JAI).

Kedua, transmisi pengetahuan atau syiar Islam di PIRI dilakukan melalui penerbitan, silaturahmi, pembaiatan, dan kegiatan PIRI itu sendiri. Dominasi transmisi pengetahuan GAI di PIRI adalah kurikulum pendidikan agama Islam di sekolah-sekolah PIRI yang memuat materi ke-PIRI-an. Materi ke-PIRI-an ini berisikan mata pelajaran ketajdidan yang awalnya disebut dengan keahmadiyahan. Namun dalam implementasinya, PIRI dan pendidikan serta lembaga sekolahnya lebih mengorientasikan diri kepada pengintegrasian kepada perubahan sosial di masyarakat, sehingga bentuk pendidikan yang dipersepsi dan diekspektasi sesuai dengan sistem pendidikan nasional. Misalnya, pendidikan untuk semua dilihat dari siswa sekolah-sekolah PIRI yang berasal dari seluruh kalangan masyarakat. Guru-guru yang mengajar harus sesuai standar nasional guru. Meskipun ada upaya transmisi pengetahuan GAI dalam bentuk materi Ke-PIRI-an pada satuan-satuan pendidikan yang berada di bawah PIRI, praktek pembelajaran pendidikan agama dilakukan dengan strategi membangun keberagamaan inklusif-dialogis berbasis multikultural baik dari sisi guru, materi, metodologi, dan orientasi.

\section{Rekomendasi}

Pertama, adanya hubungan historis dan keruhanian antara PIRI dan GAI merupakan hal yang wajar sebagai "identitas diri" PIRI dalam menyelenggarakan sebuah sistem pendidikan, karena itu masyarakat dan pemerintah tidak perlu khawatir akan eksistensi pendidikan di PIRI. Terlebih lagi, PIRI secara organisatoris bersifat otonom yang terpisah dari organisasi GAI. Upaya PIRI dalam proses pendidikan ke arah standarisasi yang dibuat pemerintah perlu didorong ke arah integrasi sistem pendidikan nasional.

Kedua, strategi pendidikan agama dalam bentuk keberagamaan inklusif-dialogis berbasis multikultural dengan orientasi, metodologi, materi yang berbeda serta sinergi dengan lembaga dan guru non-agama, perlu mendapat apresiasi dari berbagai kalangan, termasuk pemerintah, dan strategi ini dimungkinkan untuk diadopsi dalam pembelajaran pendidikan agama di sekolahsekolah lain. 


\section{SUMBER BACAAN}

Ali, Maulana Muhammad (2006): "Pengertian Hakiki Gerakan Ahmadiyah", dalam Studi Islam, Volume 1 Nomor 1 Agustus.

Anggaran Dasar dan Anggaran Rumah Tangga Gerakan Ahmadiyah Indonesia (GAI) diterbitkan oleh Pedoman Besar Gerakan Ahmadiyah Indonesia (PB GAI) Tahun 1995.

Asry, Yusuf (2013): Laporan Penelitian Gerakan Ahmadiyah Indonesia (GAI) Baciro Yogyakarta, Puslitbang Kehidupan Keagamaan Badan Litbang dan Diklat Kementerian Agama.

Dokumen Personalia Pedoman Besar Gerakan Ahmadiyah Indonesia Periode Tahun 2009-2014, Gerakan Ahmadiyah Indonesia (Ahmadiyya Anjuman Isha'ati Lahore).

Dokumen Surat Keputusan Badan Pengurus Yayasan PIRI Nomor: 085/A/PP/2013 Tentang Visi-Misi Pendidikan Agama Islam (PAI) Yayasan PIRI, tahun 2013-2018.

Farikhatin, Anis (2013): "Membangun Keberagamaan Inklusif-Dialogis di SMA PIRI I Yogyakarta", MAARIF Vol. 8, No.1-Juli.

Hansen, Judith Friedman (1979): Sociocultural Perspectives on Human Learning: An Introduction To Educational Anthropology. Prentice Hall, INC., Englewood, N.J.

Iskandar, Nanang RI (2005): Hasil Studi Banding Ahmadiyah. Jakarta, Darul Kutubi Islamiyah.
-----. (2008): Dasa Windu Gerakan Ahmadiyah Indonesia 1928-2008. Jakarta, Darul Kutubil Islamiyah.

Mulyono (2006): "Sosialisasi dan Kaderisasi GAI Sebuah Keniscayaan", dalam Kaderisasi GAI, Reaktualisasi Dakwah Islam dengan Salam, Yogyakarta, Tim Naskah Jalsah Salanah GAI 2006.

Sumaryani (1990): Sejarah Perkembangan Yayasan Perguruan Islam Republik Indonesia Yogyakarta, Sekripsi Fakultas Tarbiyah Institut Agama Islam Negeri Sunan Kalijaga Yogyakarta.

Yasir, S. Ali dan Yatiman AS. (1989): 100 Tahun Ahmadiyah, 60 Tahun Gerakan Ahmadiyah Lahore Indonesia, Media Komunikasi No.02, Pedoman Besar GAI Bagian Tabligh dan Tarbiyah.

Yasir, S.Ali (2010): Pendidikan Agama Islam untuk SMA/SMK Kelas 1, Yogyakarta, Pengurus Pusat Yayasan Perguruan Islam Republik Indonesia.

(2010): Pendidikan Agama Islam untuk SMA/SMK Kelas 2, Yogyakarta, Pengurus Pusat Yayasan Perguruan Islam Republik Indonesia.

(2010): Pendidikan Agama Islam untuk SMA/SMK Kelas 3, Yogyakarta, Pengurus Pusat Yayasan Perguruan Islam Republik Indonesia.

Zulkarnain, Iskandar (2011): Gerakan Ahmadiyah di Indonesia. Yogyakarta, LKIS. 